Supporting Information for

\title{
Enzyme-mimic peptide assembly to achieve
}

\section{amidolytic activity}

Yoke-Ming Wong ${ }^{\dagger, \#}$, Hiroyasu Masunaga ${ }^{\ddagger}$, Jo-Ann Chuah ${ }^{\dagger}$, Kumar Sudesh ${ }^{\#}$ and Keiji

$$
\text { Numata }{ }^{\dagger} *
$$

'Enzyme Research Team, RIKEN Center for Sustainable Resource Science, 2-1, Hirosawa, Wako-shi, Saitama 351-0198, Japan.

*Japan Synchrotron Radiation Research Institute, 1-1-1, Kouto, Sayo-cho, Sayo-gun, Hyogo 679-5198, Japan.

${ }^{\#}$ Ecobiomaterial Research Laboratory, School of Biological Sciences, Universiti Sains Malaysia, 11800, Minden, Penang, Malaysia.

\section{*Corresponding Author}

Keiji Numata

Tel: +81 48467 9525, Fax: +81 48462 4664, E-mail: keiji.numata@ riken.jp 

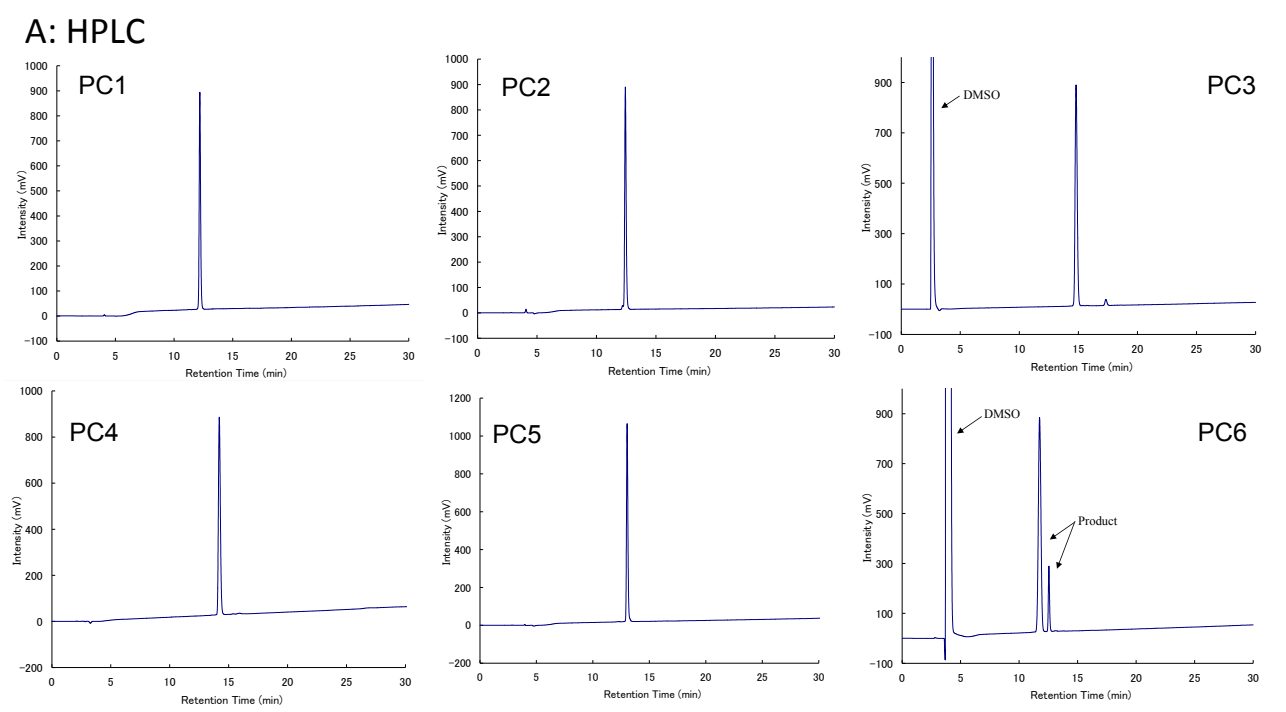

B: MALDI-TOF
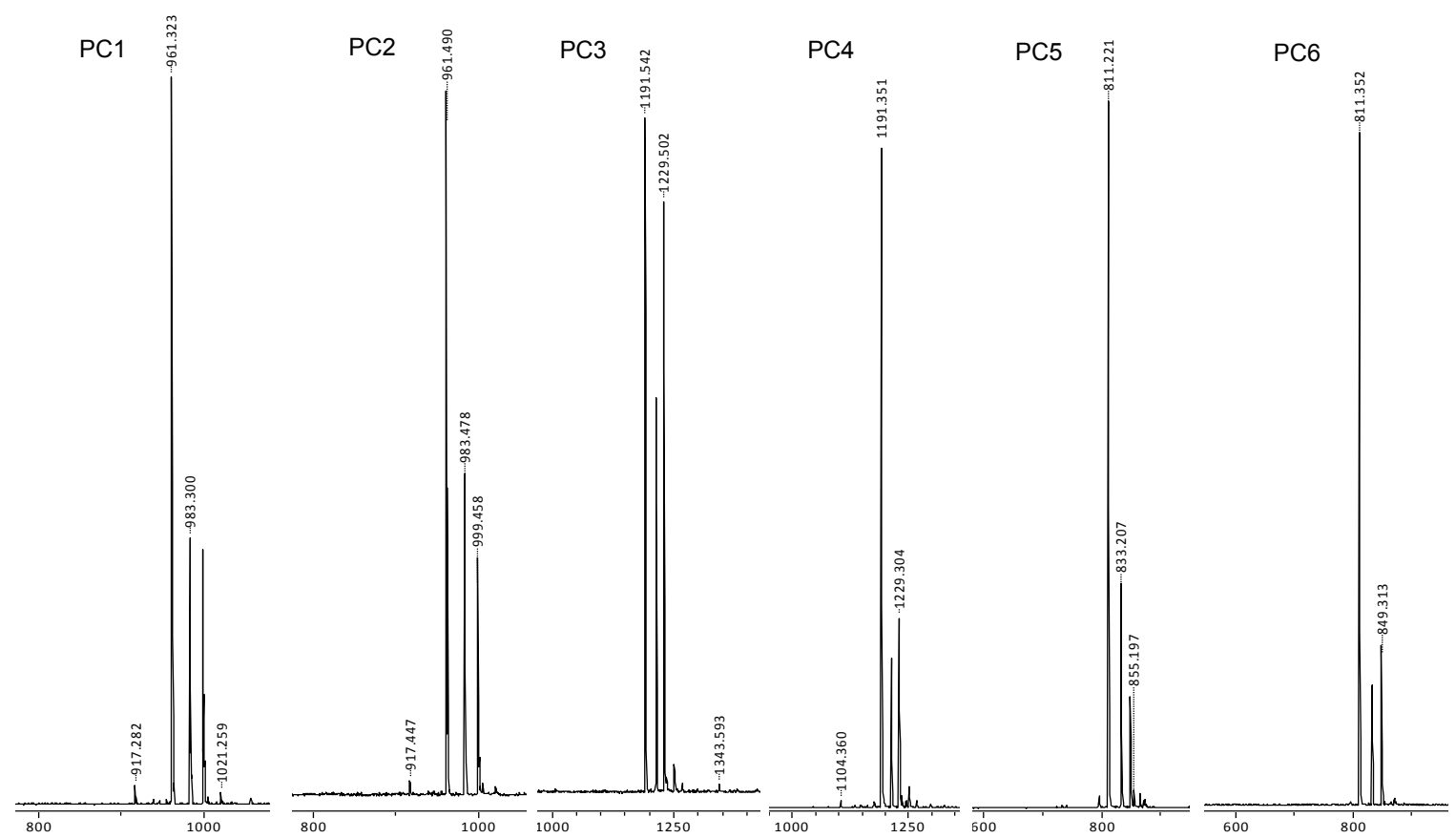

Figure S1. HPLC (A) and MALDI-TOF data (B) of PC used in this study. 


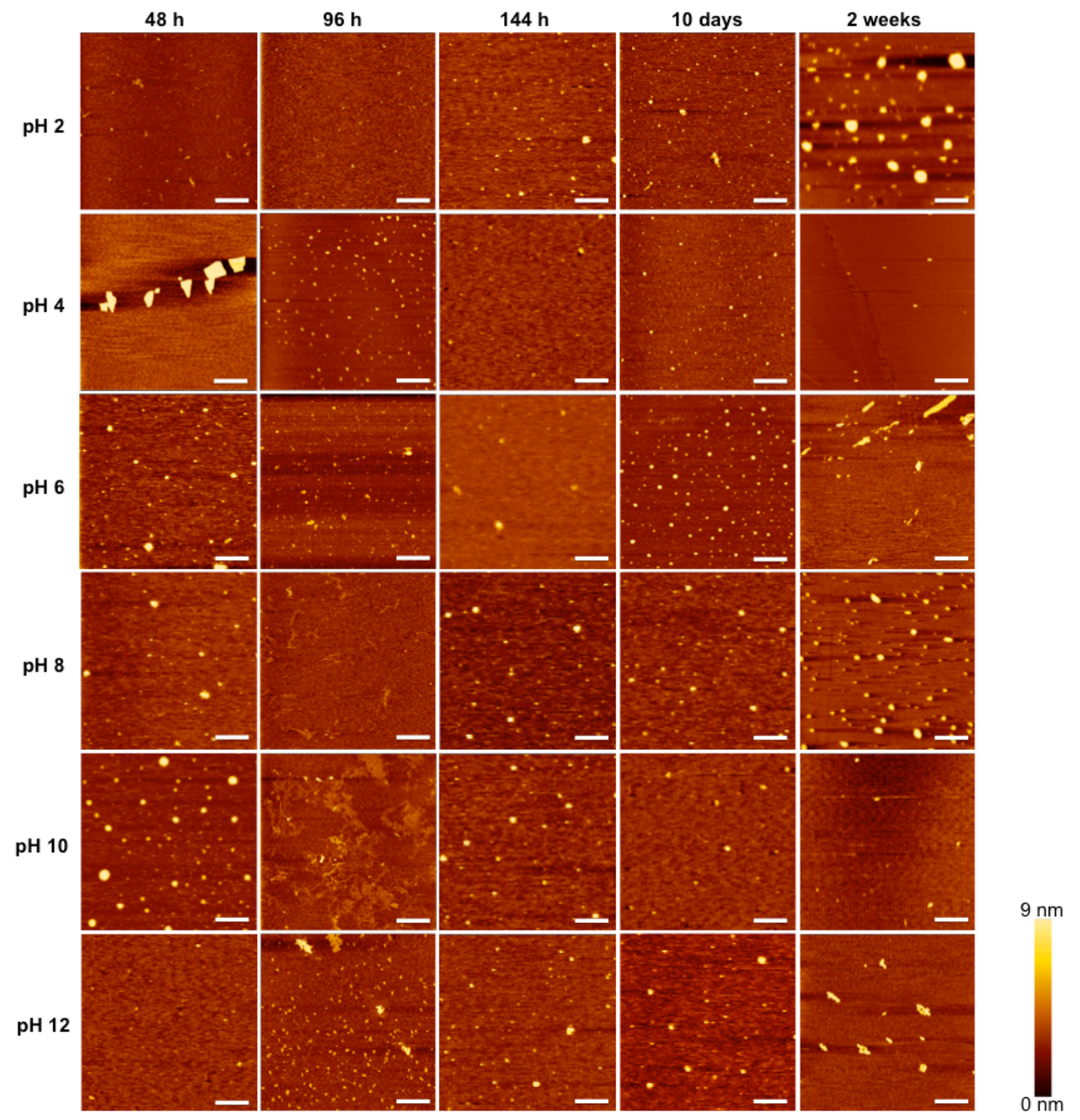

Figure S2. AFM images of PC1 fibrillated at different $\mathrm{pH}$ values and obtained at different time points at $25^{\circ} \mathrm{C}$. Scale bar: $1 \mu \mathrm{m}$. 


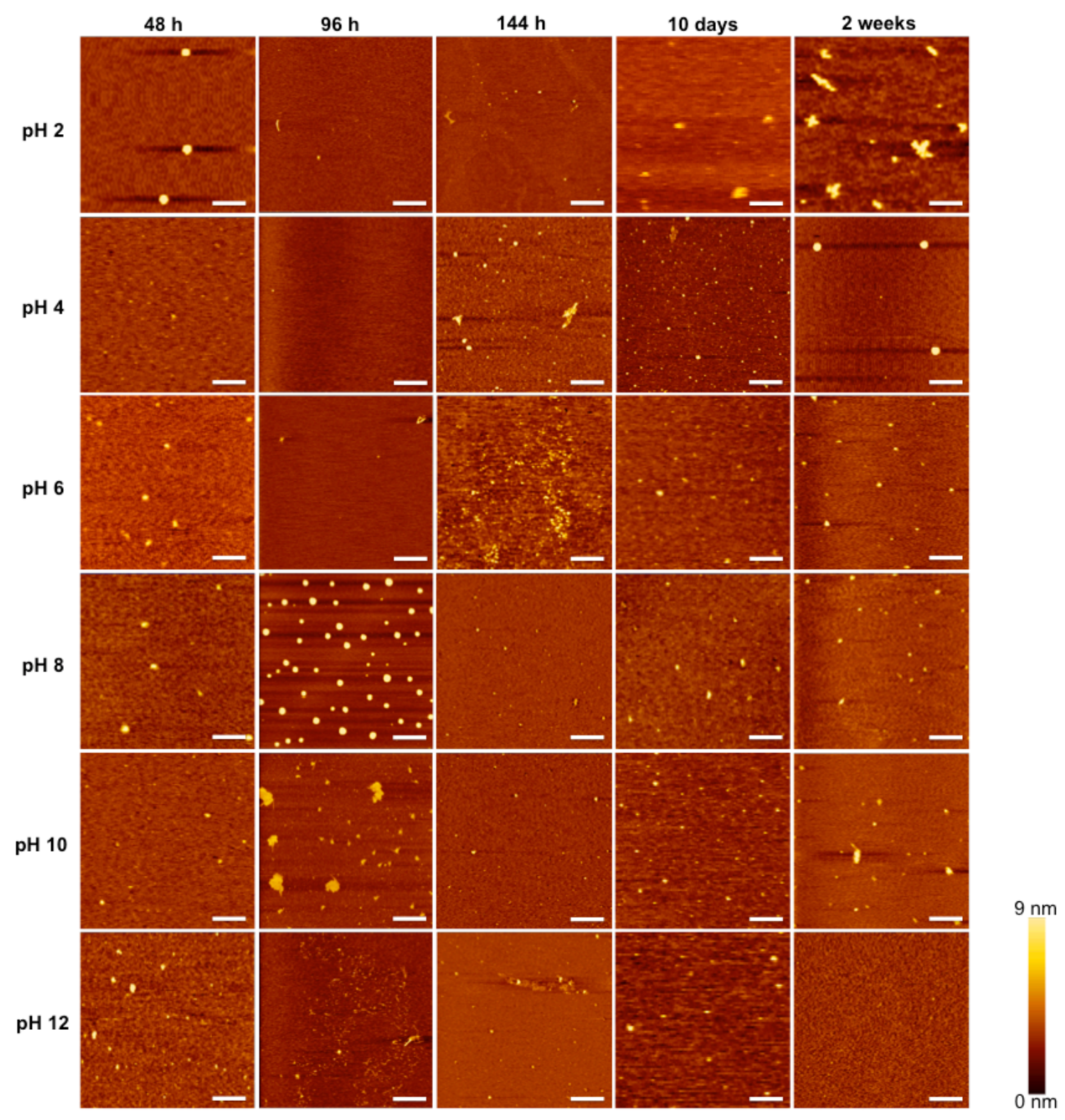

Figure S3. AFM images of PC2 fibrillated at different $\mathrm{pH}$ and obtained at different time points at $25^{\circ} \mathrm{C}$. Scale bar: $1 \mu \mathrm{m}$. 


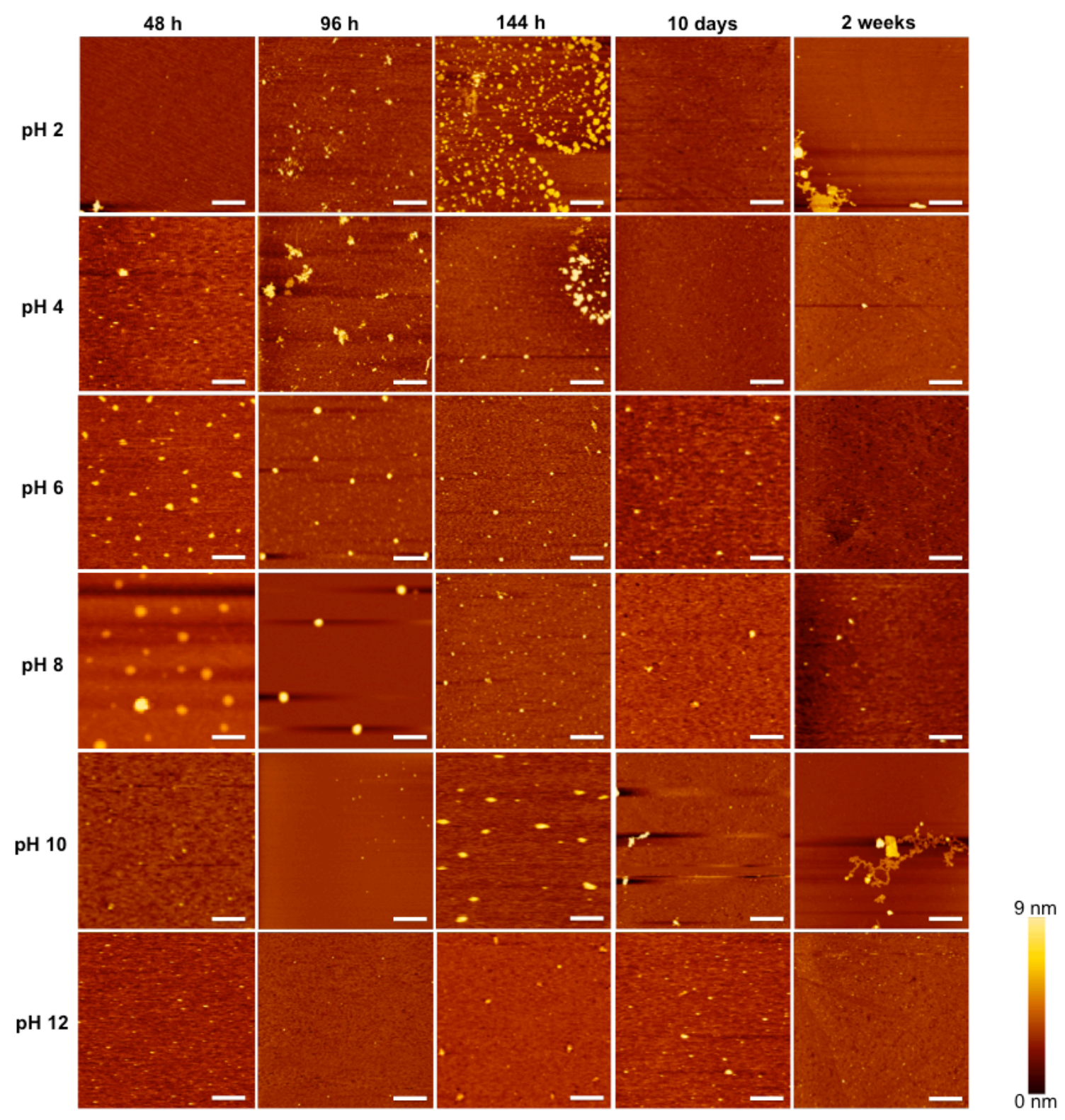

Figure S4. AFM images of PC5 fibrillated at different $\mathrm{pH}$ and obtained at different time points at $25^{\circ} \mathrm{C}$. Scale bar: $1 \mu \mathrm{m}$. 


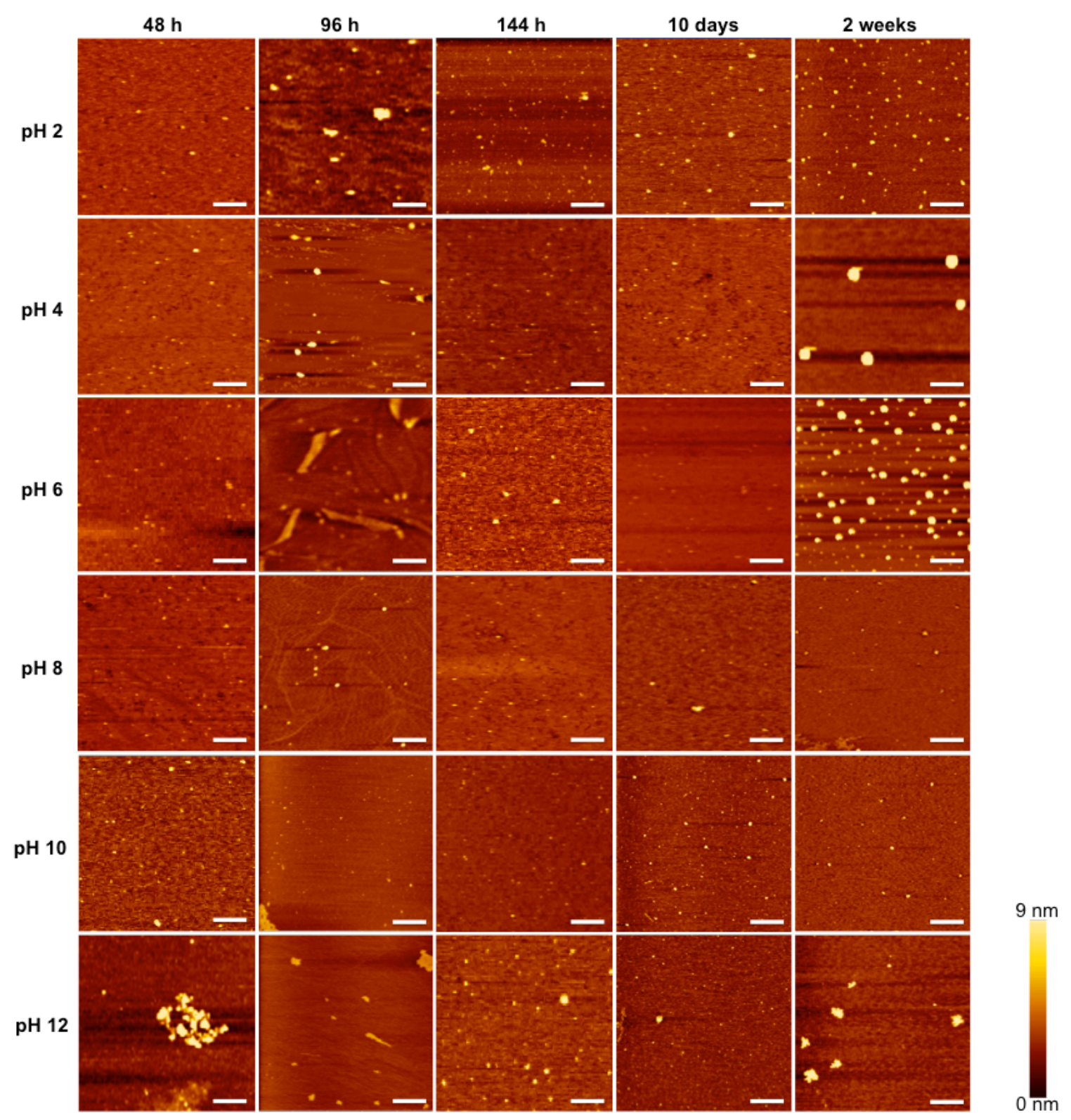

Figure S5. AFM images of PC6 fibrillated at different $\mathrm{pH}$ and obtained at different time points at $25^{\circ} \mathrm{C}$. Scale bar: $1 \mu \mathrm{m}$. 

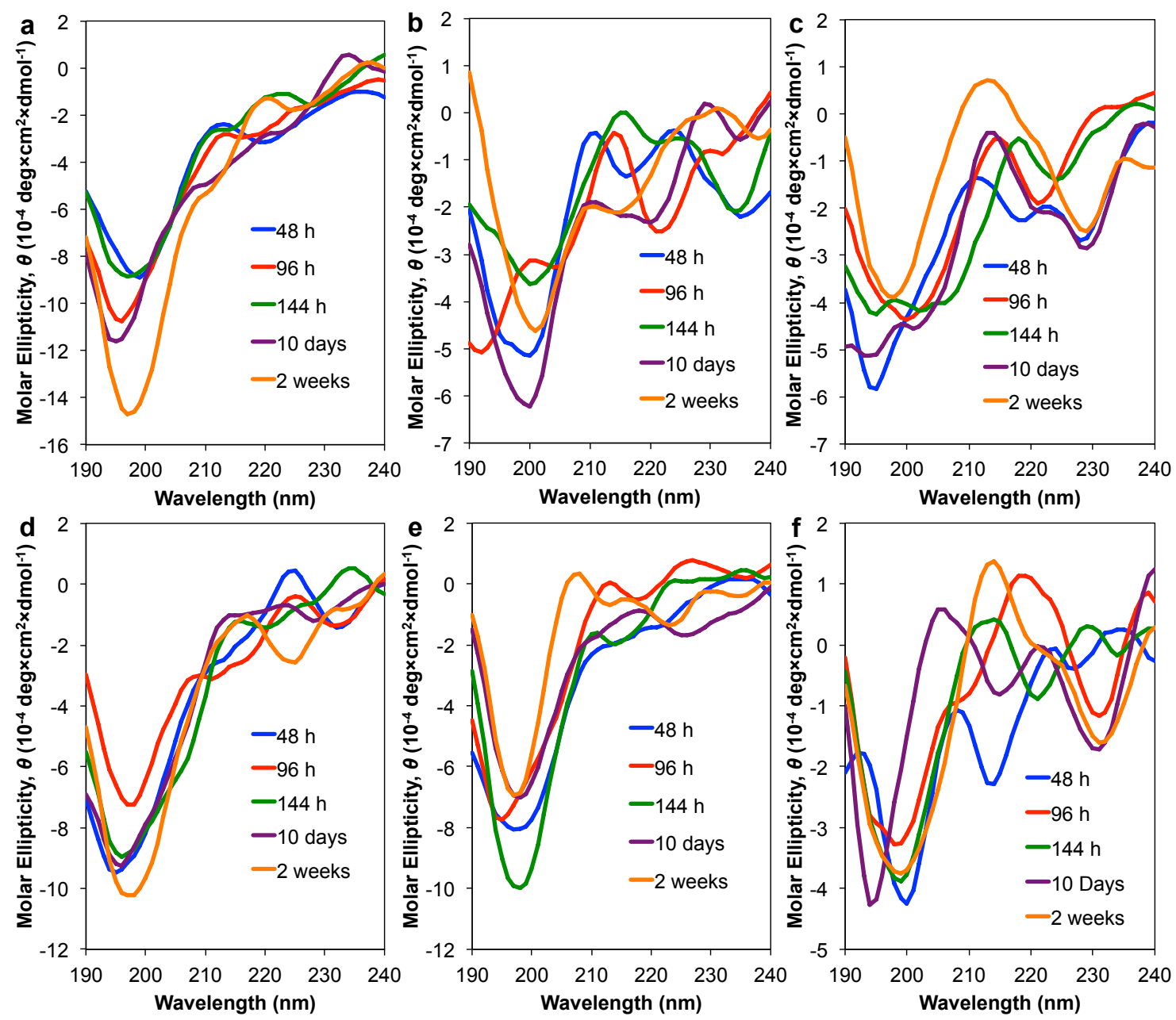

Figure S6. CD spectra of PC1 fibrillated at different $\mathrm{pH}$ and collected at different time points at $25^{\circ} \mathrm{C}$ : (a) $\mathrm{pH} \mathrm{2,} \mathrm{(b)} \mathrm{pH} 4$, (c) $\mathrm{pH} \mathrm{6,} \mathrm{(d)} \mathrm{pH} 8$, (e) $\mathrm{pH} 10$, and (f) $\mathrm{pH} 12$. Peptide concentration is $10 \mu \mathrm{M}$. 

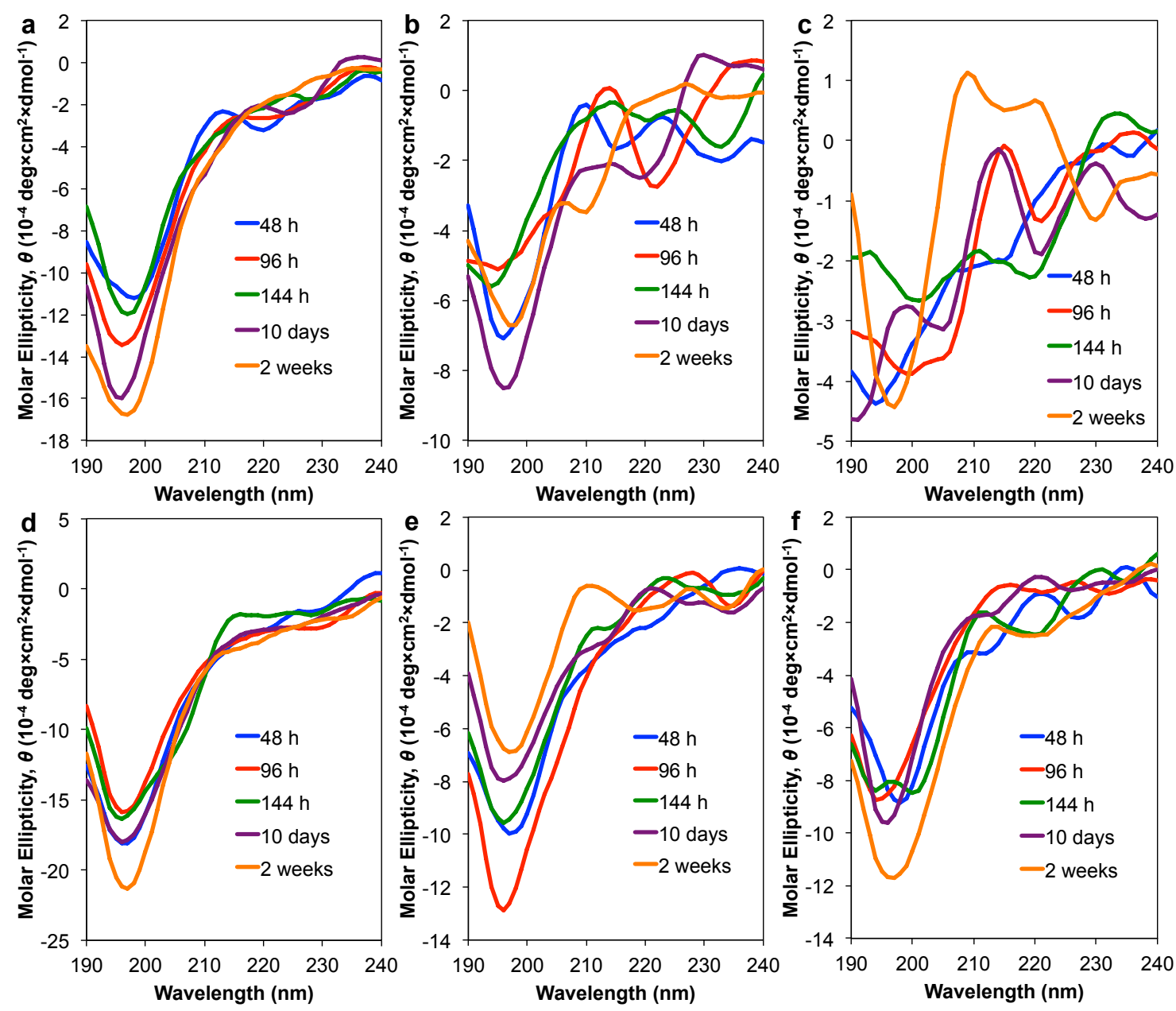

Figure S7. CD spectra of PC2 fibrillated at different $\mathrm{pH}$ and collected at different time points at $25^{\circ} \mathrm{C}$ : (a) $\mathrm{pH} \mathrm{2,} \mathrm{(b)} \mathrm{pH} 4$, (c) $\mathrm{pH} \mathrm{6,} \mathrm{(d)} \mathrm{pH} 8$, (e) $\mathrm{pH} \mathrm{10,} \mathrm{and} \mathrm{(f)} \mathrm{pH} 12$. Peptide concentration is $10 \mu \mathrm{M}$. 

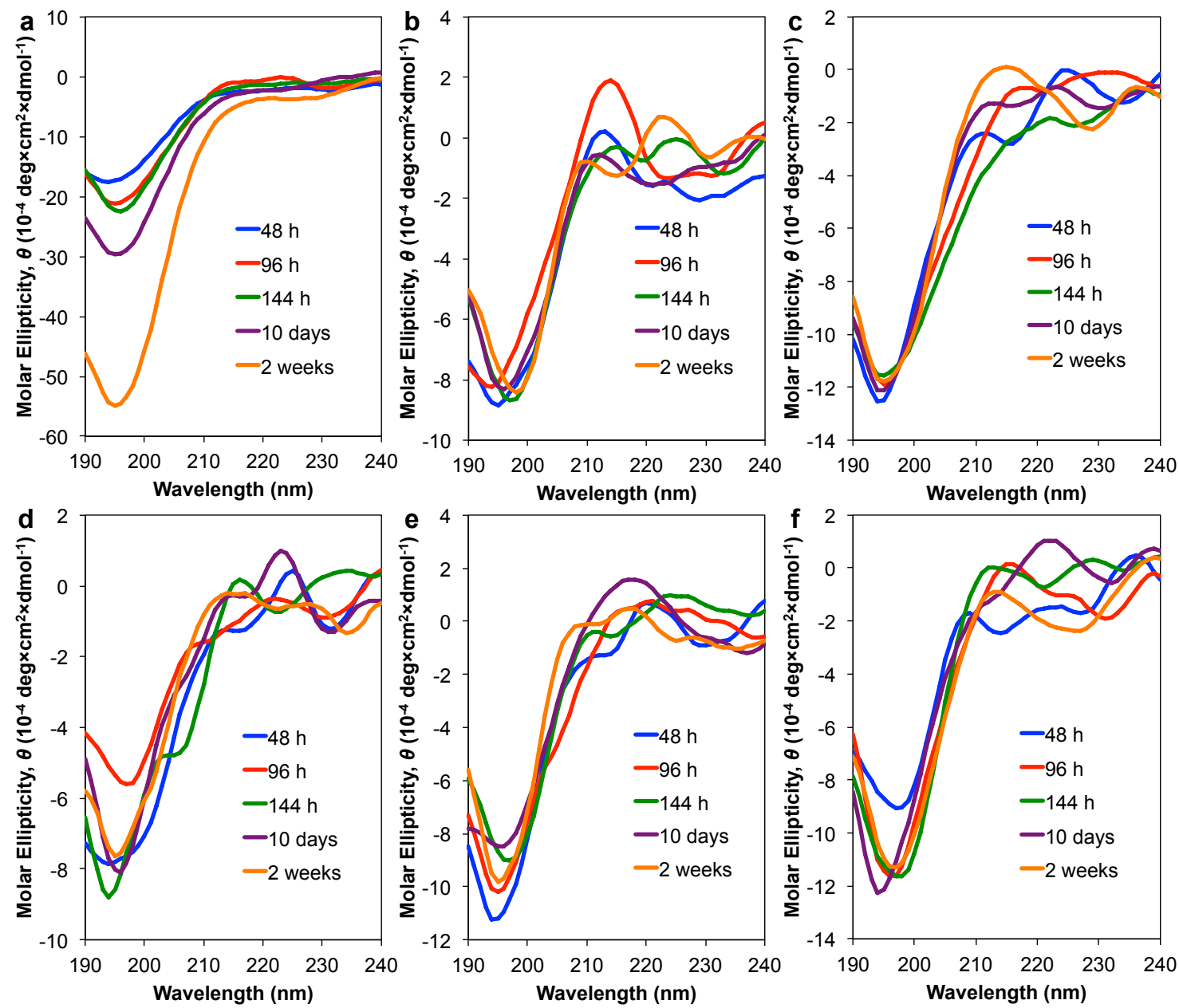

Figure S8. CD spectra of PC5 fibrillated at different $\mathrm{pH}$ and collected at different time points at $25^{\circ} \mathrm{C}$ : (a) $\mathrm{pH} \mathrm{2,} \mathrm{(b)} \mathrm{pH} 4$, (c) $\mathrm{pH} \mathrm{6,} \mathrm{(d)} \mathrm{pH} 8$, (e) $\mathrm{pH} 10$, and (f) $\mathrm{pH} 12$. Peptide concentration is $10 \mu \mathrm{M}$. 

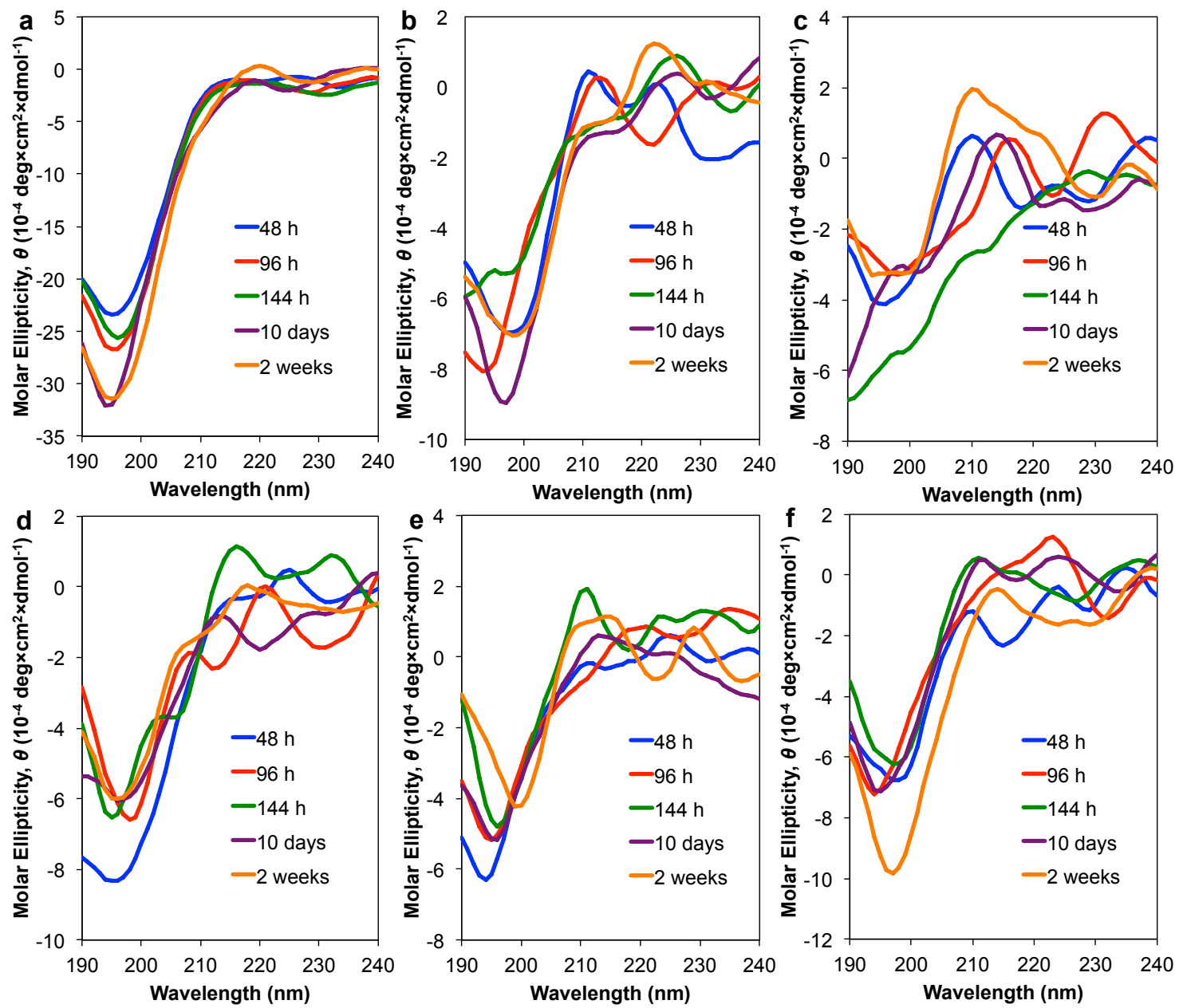

Figure S9. CD spectra of PC6 fibrillated at different $\mathrm{pH}$ and collected at different time points at $25^{\circ} \mathrm{C}$ : (a) $\mathrm{pH} \mathrm{2,} \mathrm{(b)} \mathrm{pH} 4$, (c) $\mathrm{pH} \mathrm{6,} \mathrm{(d)} \mathrm{pH} 8$, (e) $\mathrm{pH} \mathrm{10,} \mathrm{and} \mathrm{(f)} \mathrm{pH} 12$. Peptide concentration is $10 \mu \mathrm{M}$. 

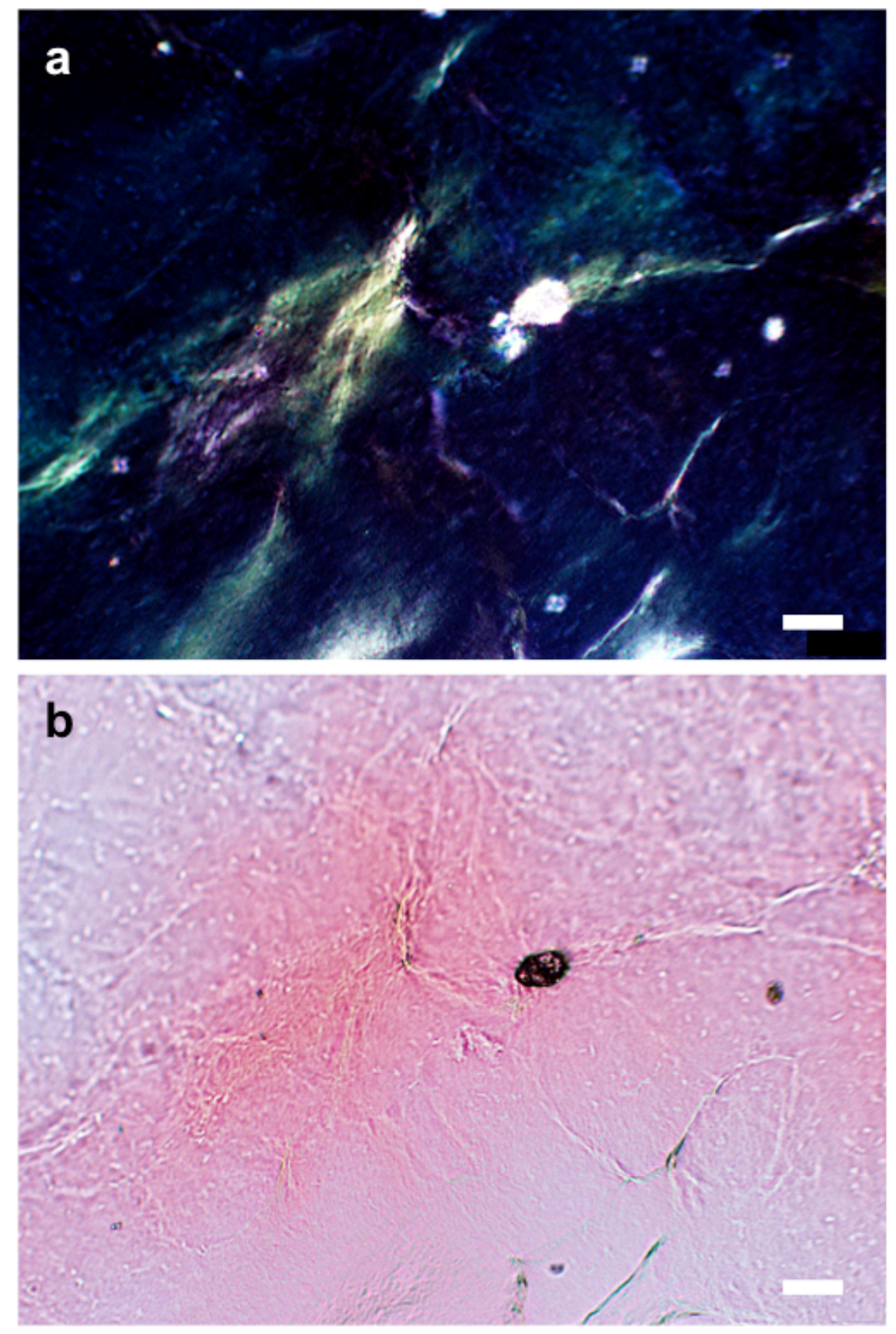

Figure S10. Optical microscope images of Bombyx mori silk as positive control, were taken under cross-polarized light stained with Congo red. (a) B. mori showed green birefringence coming from regions rich in $\beta$-sheet structures. (b) Non-polarized images of B. mori; scale bar: $20 \mu \mathrm{m}$. 

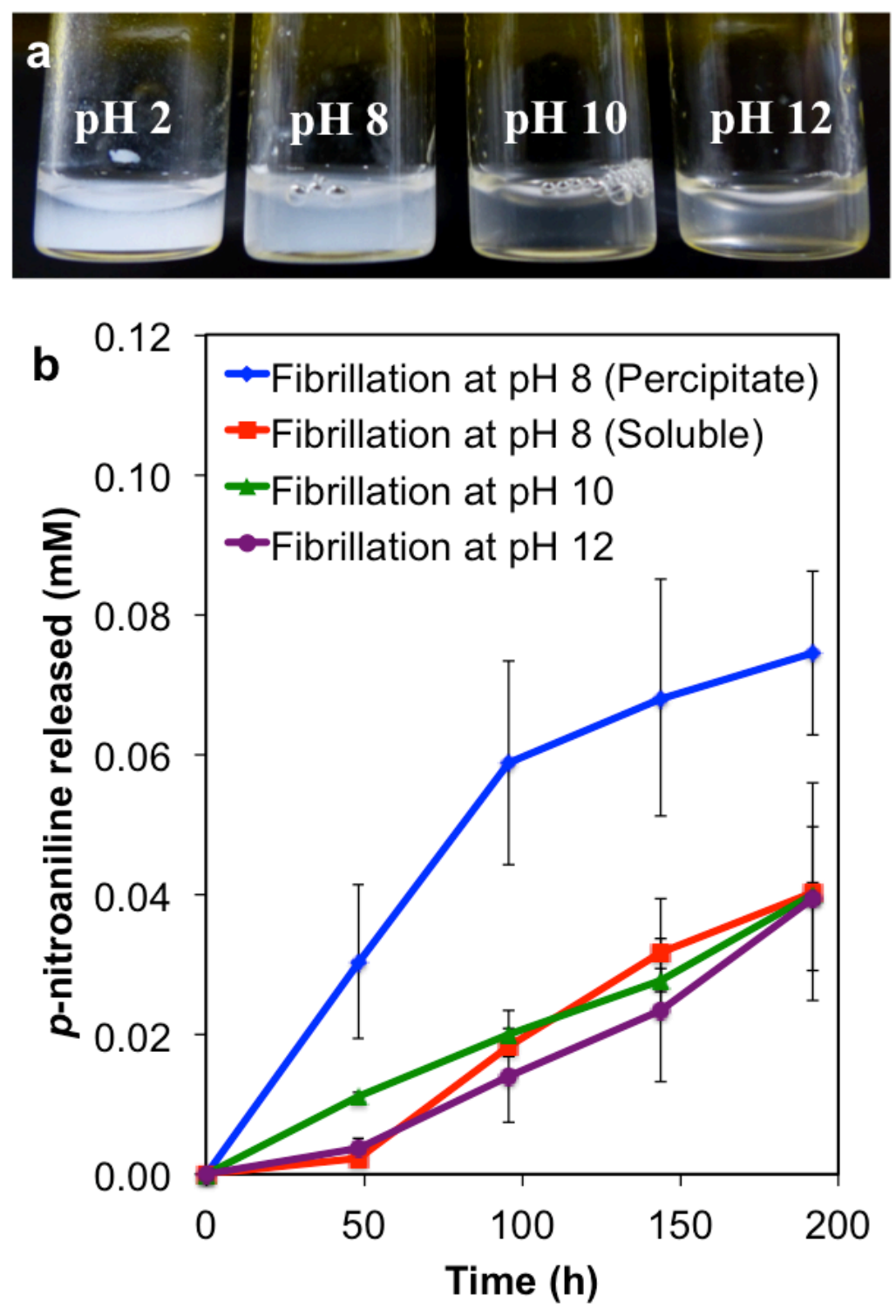

Figure S11. (a) The PC solution becomes viscous and transparent when the incubation $\mathrm{pH}$ increases from $\mathrm{pH} 8$ to $\mathrm{pH} 10$ and 12. (b) Amidase activity with a substrate, L-alanine p-nitroanilide $(0.25 \mathrm{mM})$, using soluble fibrils of $\mathrm{PC} 4$ at $25^{\circ} \mathrm{C}, \mathrm{pH} 8$ to confirm the less active soluble form of PC4. All data shown are the means of triplicate tests. 

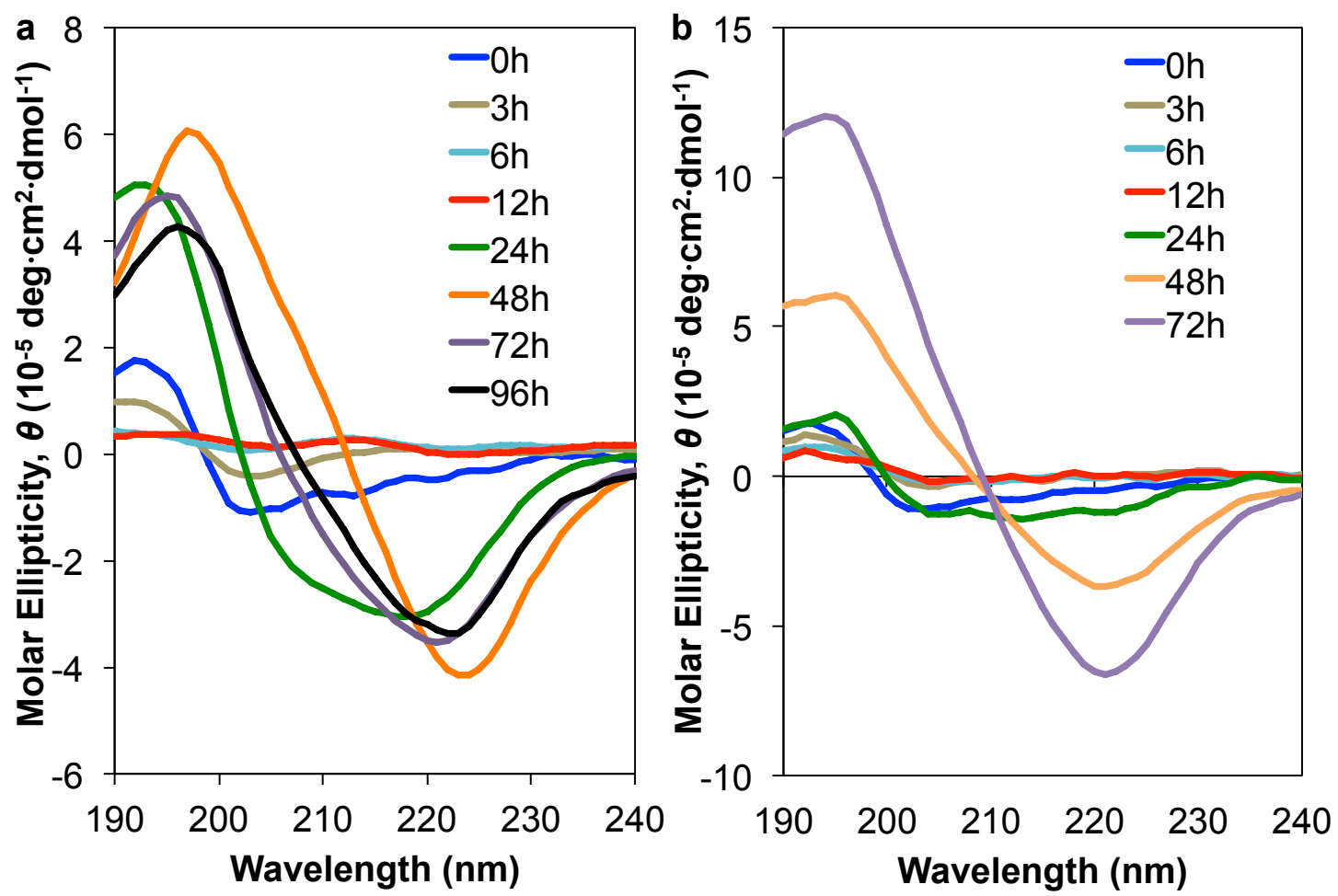

Figure S12. CD spectra of PC4 fibrillated at $50^{\circ} \mathrm{C}$ (a) and $70^{\circ} \mathrm{C}$ (b) at different time points. 

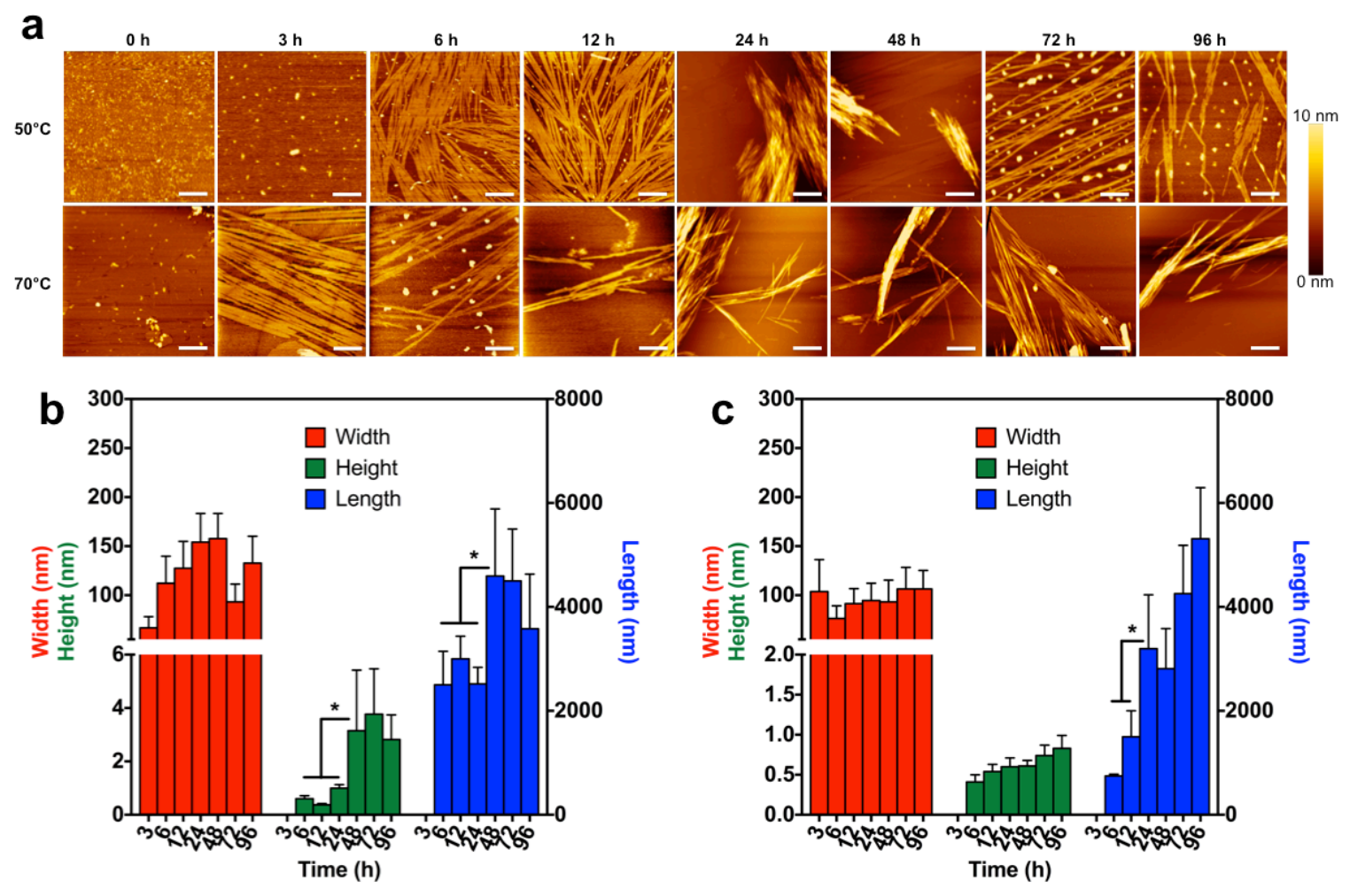

Figure S13. (a) AFM images of PC4 fibrillated at different temperature and obtained at different time points at $25^{\circ} \mathrm{C}$. Scale bar: $1 \mu \mathrm{m}$. The size distributions of PC4 fibrillated at $50^{\circ} \mathrm{C}(\mathrm{b})$ and $70^{\circ} \mathrm{C}$ (c) in terms of width, height, and length of fibrillated fibers at different $\mathrm{pH}$ with different incubation times. All data shown are the means of replicate tests $(n=30)$, and mean data accompanied by asterisks $(*)$ are significantly different (Tukey's HSD test; $p<0.05$ ). 

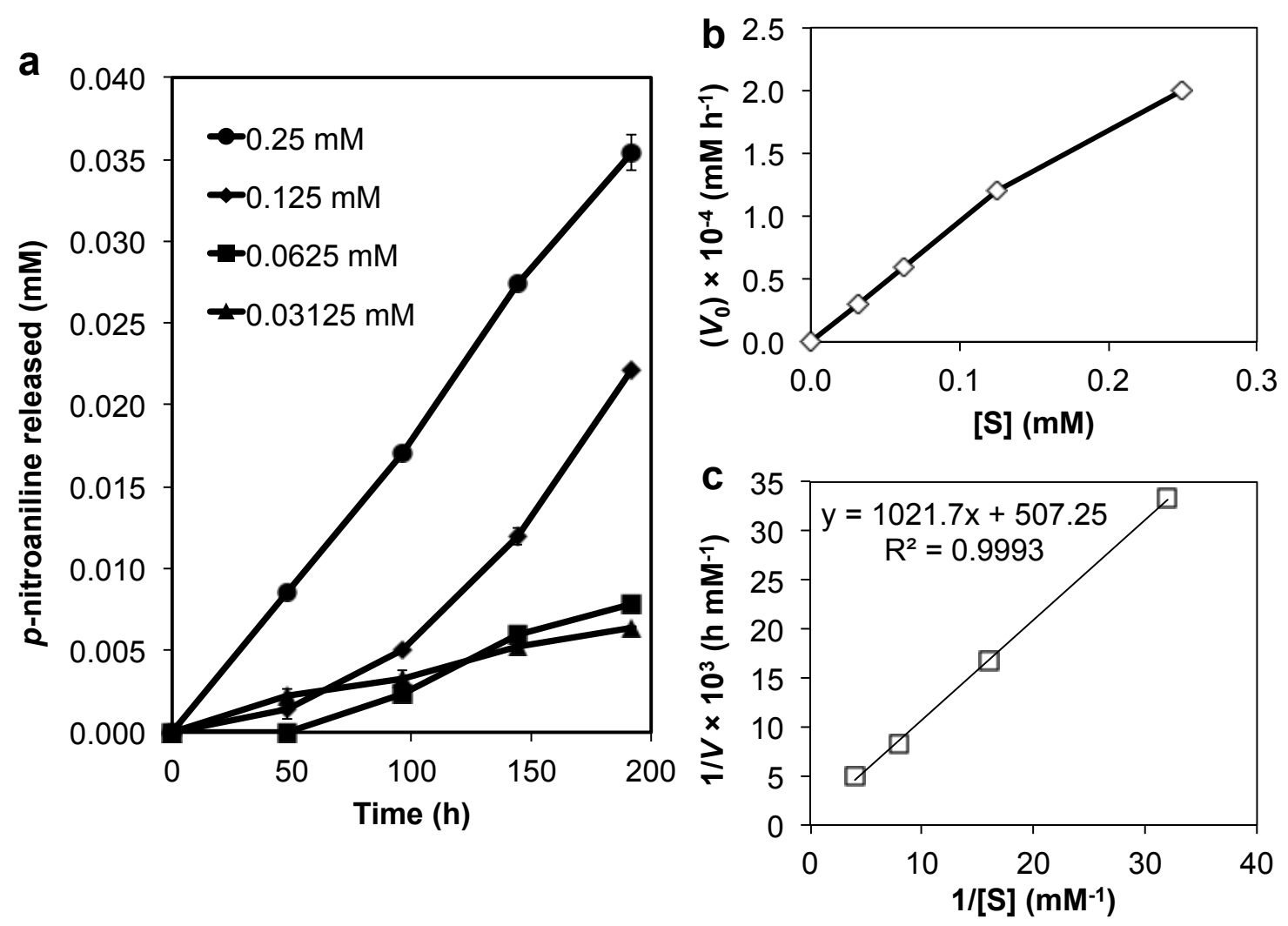

Figure S14. Amidase activity on different concentrations of substrates, L-alanine- $p$ nitroanilide using $2 \mathrm{mM}$ of $\mathrm{PC} 4$ at $25^{\circ} \mathrm{C}, \mathrm{pH}$ 8. (a) Amount of $p$-nitroaniline released as a function of time. Initial velocity obtained was plotted as (b) Michaelis-Menten plot and followed by (c) Lineweaver-Burk plot to determine the catalytic constants. All data shown are the means of triplicate tests. 
Table S1. Analyses of the secondary structures of PCs from the CD data.

\begin{tabular}{|c|c|c|c|}
\hline \multirow{2}{*}{ PC (at different pH) } & \multicolumn{3}{|c|}{ Estimated secondary structure $(\%)^{\mathrm{a}}$} \\
\hline & $\alpha$-helix & $\beta$-strand & Random \\
\hline \multicolumn{4}{|l|}{ PC3 } \\
\hline pH 2 & 33.4 & 66.6 & - \\
\hline pH 4 & 17.2 & - & 82.8 \\
\hline pH 6 & 12.3 & - & 87.7 \\
\hline pH 8 & - & 54.0 & 46.0 \\
\hline pH 10 & 53.1 & 24.0 & 22.9 \\
\hline pH 12 & 93.0 & 7.0 & - \\
\hline \multicolumn{4}{|l|}{ PC4 } \\
\hline pH 2 & 83.4 & 16.6 & - \\
\hline pH 4 & 35.4 & - & 64.6 \\
\hline pH 6 & 11.4 & - & 88.6 \\
\hline pH 8 & 5.4 & 93.6 & 1.0 \\
\hline pH 10 & 7.8 & 69.6 & 22.6 \\
\hline pH 12 & 26.6 & 58.4 & 15.0 \\
\hline
\end{tabular}

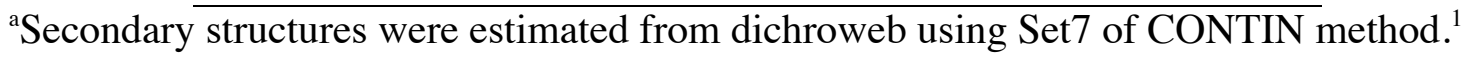




\section{REFERENCES}

(1) Whitmore, L.; Wallace, B. A. Biopolymers 2008, 89, 392-400. 